\title{
Spectroscopic investigation, DFT calculations and cytotoxic activity of a 1-amino-1,3-dihydrospiro[imidazoline-4,2-indene]-2,5-dione and its platinum and palladium complexes
}

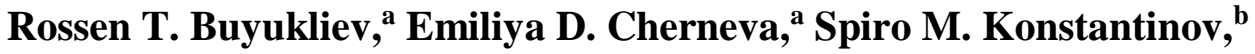 \\ and Adriana G. Bakalova*a \\ ${ }^{a}$ Department of Chemistry, Faculty of Pharmacy, Medical University - Sofia, 2 Dunav Str., \\ 1000 Sofia, Bulgaria \\ ${ }^{b}$ Department of Pharmacology, Pharmacotherapy and Toxicology, Faculty of Pharmacy, \\ Medical University-Sofia, 2 Dunav Str., 1000 Sofia, Bulgaria \\ E-mail: adrigebk@abv.bg
}

DOI: https://doi.org/10.24820/ark.5550190.p009.939

\begin{abstract}
1-Amino-1,3-dihydrospiro[imidazoline-4,2-indene]-2,5-dione and its $\mathrm{Pt}(\mathrm{II})$ and $\mathrm{Pd}(\mathrm{II})$ complexes were synthesized. The structures of the compounds were characterized by elemental analysis, IR, ${ }^{1} \mathrm{H}$ and ${ }^{13} \mathrm{C}$ NMR spectra. The analyses indicated that the complexes have general formula cis$\left[\mathrm{ML}_{2} \mathrm{Cl}_{2}\right]$ and the ligand coordinatedvia nitrogen atom from $\mathrm{NH}_{2}$ group. The molecular structure of the ligand and its $\mathrm{Pt}(\mathrm{II})$ and $\mathrm{Pd}(\mathrm{II})$ complexes were studied computationally by hybrid DFT calculations. Theoretical analysis of the complexes confirmed that the cis-isomers are more stable than trans and complexes exhibit square planar coordination. The cytotoxic activity of the new ligand and its complexes was determined in vitro by MTT assay against K-562 and HL-60 human tumor cell lines. The $\mathrm{IC}_{50}$ values of the tested compounds showed that the Pt(II) complex with 1amino-1,3-dihydrospiro[imidazoline-4,2-indene]-2,5-dione has higher cytotoxic activity than the palladium(II) complex with the same ligand, which confirmed that platinum complexes show higher activity than the corresponding palladium complexes.
\end{abstract}

Keywords: Pt and Pd complexes, spirohydantoins, DFT calculations, cytotoxicity

\section{Introduction}

Cisplatin is one of the most widely used anticancer drugs for the treatment of diverse solid tumours such as head and neck, squamous cell carcinoma, ovarian cancer, cervical cancer, urinary bladder cancer etc. ${ }^{1-3}$ Despite its wide application, cisplatin is associated with many serious side effects like nephrotoxicity, ototoxicity, myelotoxicity, peripheral neuropathy and hematological toxicity. ${ }^{4-}$ 
${ }^{6}$ Because of side effects and limited number of cancer types sensitive to cisplatin, other platinum, ruthenium, rhodium, gold, titanium or palladium complexes have been synthesized and investigated for cytotoxic activity. ${ }^{7-9}$ On the basis of the structural analogy between $\mathrm{Pt}(\mathrm{II})$ and Pd(II) complexes, some studies of palladium compounds as suitable drugs have been carried out. ${ }^{10}$ The geometry and complex forming processes of palladium(II) are very similar to those of platinum(II) therefore it was speculated that palladium complexes may also have antitumour activity and serve as good models for the understanding of more inert platinum(II) anticancer drugs. ${ }^{11-14}$ In order to obtain compounds with higher cytotoxicity, and lower side toxic effects than cisplatin, a new class of platinum(II) ${ }^{15,16}$ and palladium(II) complexes ${ }^{17}$ were synthesized. Hydantoins form a large group of derivatives widely applied in medicine and pharmacy, especially as anticonvulsants, antiarrhythmics, antibacterial drugs, cytotoxic agents, etc. ${ }^{18}$

The present paper describes the synthesis, identification and cytotoxic activity of two new Pt(II) and $\mathrm{Pd}(\mathrm{II})$ complexes $\mathbf{( 1 , 2 )}$ with 1-amino-1,3-dihydrospiro[imidazoline-4,2-indene]-2,5-dione as a ligand (L). This compound was obtained via different synthetic route to that used by Beard and co-workers. ${ }^{19}$

\section{Results and Discussion}

Synthesis of the $(\mathbf{L})$ and complexes $(\mathbf{1 , 2})$ are given in Scheme 1. The elemental analyses of the ligand $(\mathbf{L})$ and new metal complexes $(\mathbf{1 , 2})$ correspond to the formulae: $\mathrm{C}_{11} \mathrm{H}_{11} \mathrm{~N}_{3} \mathrm{O}_{2}(\mathbf{L})$, $\left[\mathrm{Pt}\left(\mathrm{C}_{11} \mathrm{H}_{11} \mathrm{~N}_{3} \mathrm{O}_{2}\right)_{2} \mathrm{Cl}_{2}\right]$ (1) and $\left[\mathrm{Pd}\left(\mathrm{C}_{11} \mathrm{H}_{11} \mathrm{~N}_{3} \mathrm{O}_{2}\right)_{2} \mathrm{Cl}_{2}\right]$ (2). In order to evaluate the mode of coordination of the ligand to the metal ions, IR, ${ }^{1} \mathrm{H}$ and ${ }^{13} \mathrm{C}$ NMR spectra of the ligand as well as of its platinum and palladium complexes were measured.

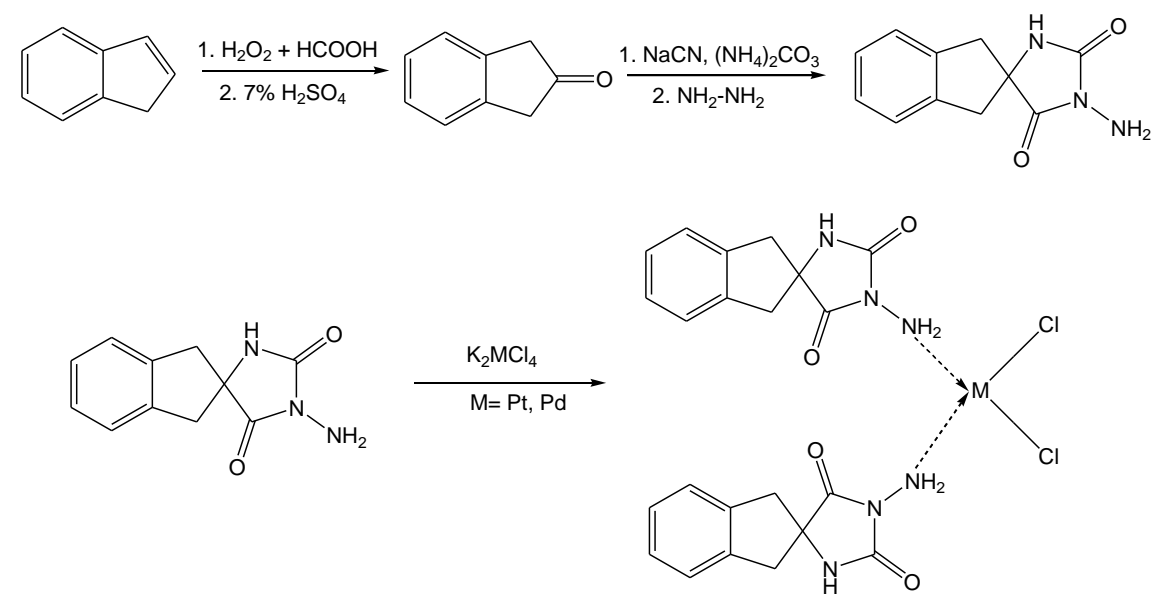

Scheme 1. Synthesis of the ligand (L) and its $\mathrm{Pt}(\mathrm{II})$ and $\mathrm{Pd}(\mathrm{II})$ complexes (1) and (2).

The IR spectrum of the ligand showed that the asymmetric and symmetric stretching vibrations of the $\mathrm{NH}_{2}$ group give rise of several bands at 3328, 3183 and $3114 \mathrm{~cm}^{-1}$ (according to Nakanishi ${ }^{20}$ ) 
due to the formation of internal hydrogen bonds in the solid state. In the spectra of the complexes these were shifted to higher frequencies: $3367 \mathrm{~cm}^{-1}(\mathbf{1})$ and $3387 \mathrm{~cm}^{-1}(\mathbf{2})$ corresponding to asymmetric $\mathrm{NH}_{2}$ modes and $3185,3147 \mathrm{~cm}^{-1}(\mathbf{1})$ and $3194,3149 \mathrm{~cm}^{-1}(\mathbf{2})$ assigned respectively to the symmetric $\mathrm{NH}_{2}$ modes. The band of deformation vibration of the $\mathrm{NH}_{2}$ was observed at 1608 $\mathrm{cm}^{-1}$ in the ligand while in the complexes it was shifted to lower frequencies and appeared at 1575 $\mathrm{cm}^{-1}$. This indicates that coordination of the ligand to metal ions is through the $\mathrm{N}$-atom of the $\mathrm{NH}_{2}$ group. A similar coordination mode was established for $\mathrm{Pt}(\mathrm{IV})$ complexes with 3-aminocyclohexanespiro-5'-hydantoin and 3-aminocycloheptanespiro-5'-hydantoin. ${ }^{21}$ In all cases bands for the stretching vibrations of the NH group (amide) were observed at $3260 \mathrm{~cm}^{-1}$. The frequencies of the stretching vibrations of the two $\mathrm{C}=\mathrm{O}$ groups are slightly lowered in the spectra of the complexes in comparison to that of the ligand.

In the ${ }^{1} \mathrm{H}$ NMR spectra of the ligand, recorded in DMSO- $d_{6}$, the signal of $\mathrm{NH}(1)$ was at 8.59 ppm, the signals of two diastereotopic $\mathrm{CH}_{2}$ groups in the 3.33-3.03 ppm range] and the $\mathrm{N}^{-\mathrm{NH}_{2}}$ protons resonated as a singlet at $4.74 \mathrm{ppm}$ (atom numbering according to Figure 1).

A comparative analysis of the ${ }^{1} \mathrm{H}$ NMR spectra of the complexes $(\mathbf{1 , 2})$ and metal-free ligand revealed that there was a significant shift of the signal of the $\mathrm{N}_{-} \mathrm{NH}_{2}$ group (from 4.74 in the metalfree ligand to 7.2-7.3 ppm in the complexes). The signals of the other protons were not significantly shifted, confirmning that the coordination of the ligand with metal ions was realized by the amino nitrogen atom.

In the ${ }^{13} \mathrm{C}$ NMR spectra, the signals of the two carbonyl carbons were slightly influenced in the complexes but all other carbon signals were not shifted significantly.

Theoretical calculations were used to predict the most stable structures and to obtain important information about structural characteristics and spectroscopic properties of the ligand and its complexes. The optimized structures of the ligand, complexes $(\mathbf{1 , 2})$ and atom numbering are presented in Figures 1-3. The optimized geometry of the ligand in the gas phase showed that the atoms lie in two planes oriented perpendicularly to each other. The first comprises the hydantoin fragment together with an $\mathrm{NH}_{2}$ group and the other, the indane fragment.

In order to determine the preferred geometry we carried out an analysis on the potential energy surface of complexes at the B3LYP/LAN2DZ level of theory. For each complex, the most probable conformations (three for trans- and three for cis-) were constructed and optimized. This showed that the cis-isomer is more stable than the trans-structure. The location of the ligands around the metal ions leads to formation of square-planar geometry in both complexes with the angles summing to $359.9^{\circ}$. 


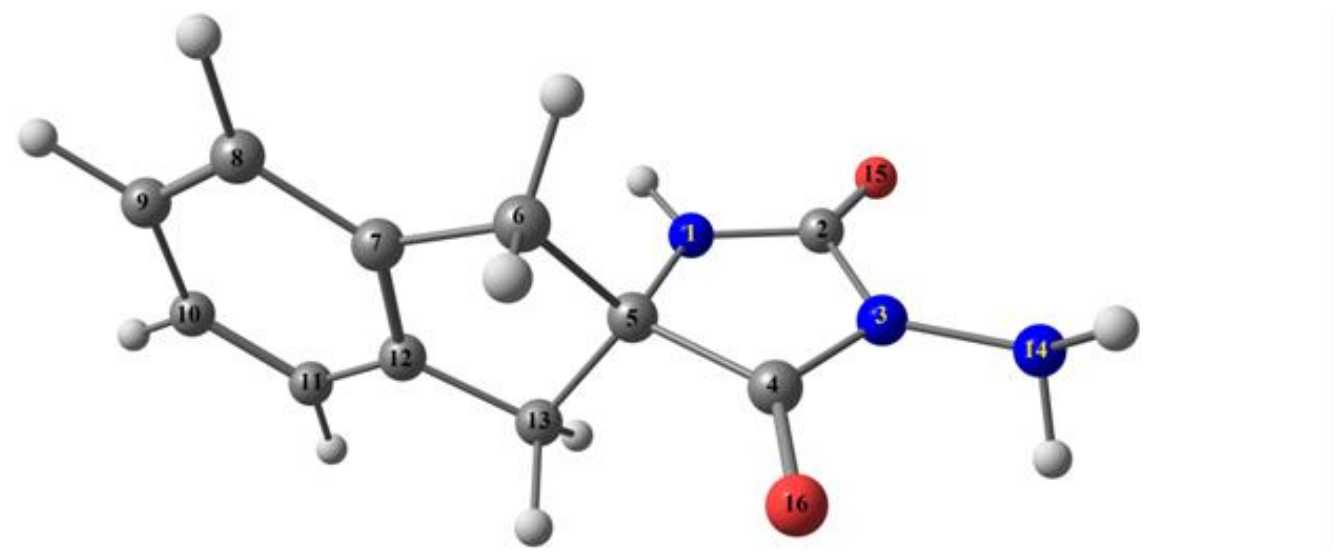

Figure 1. Optimized structure of the ligand (L), performed at DFT/ B3LYP/6-311++G** level.

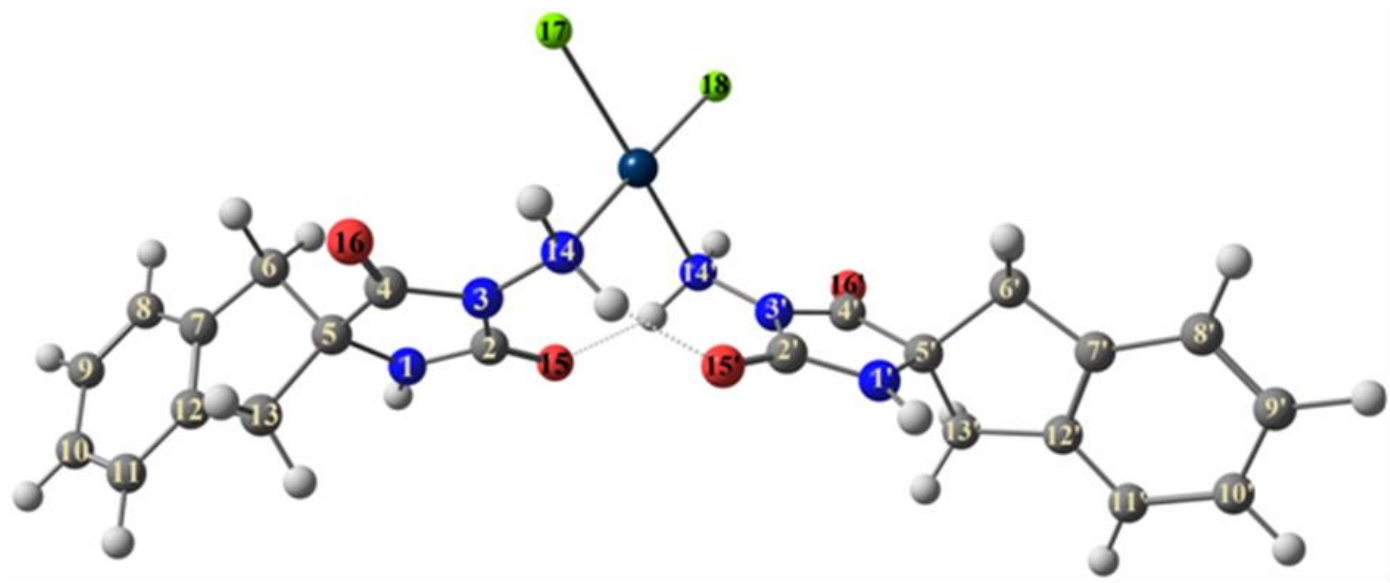

Figure 2. Optimized structure of the $c i s-\left[\mathrm{Pt}(\mathrm{L})_{2} \mathrm{Cl}_{2}\right]$ (1) performed at DFT/ B3LYP/LANL2DZ level.

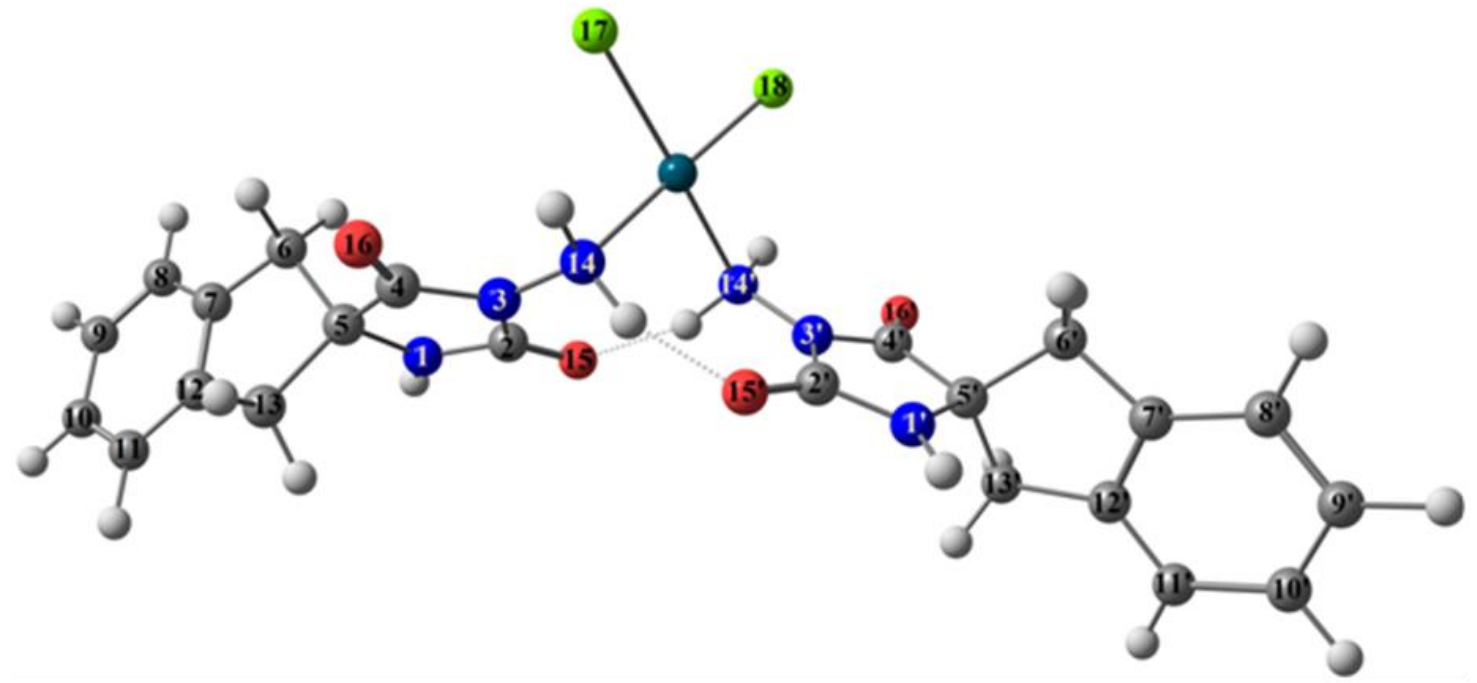

Figure 3. Optimized structure of the $c i s-\left[\mathrm{Pd}(\mathrm{L})_{2} \mathrm{Cl}_{2}\right]$ (2) performed at DFT/B3LYP/LANL2DZ level. 
The most important geometrical parameters for the ligand and the energetically preferred structures of the complexes, obtained at B3LYP level of theory are summarized in Table 1. The calculations showed that the two complexes $(\mathbf{1 , 2})$ have a quite similar geometry as can be seen in Figures 1 and 2. In both complexes one ligand is located above a plane formed by the metal ion, $\mathrm{Cl17}$, Cl18, N14, N14' while the second one is beneath the plane. The complexes are stabilized by formation of two hydrogen bonds between the $\mathrm{NH}_{2}$ and $\mathrm{C}=\mathrm{O}$ groups. The structural parameters of the internal hydrogen bonds in the complexes are presented in Table 2.

Upon coordination of the $\mathrm{NH}_{2}$ groups to the metal atom the N3-N14 bond length becomes slightly longer than in the free ligand. Coordination also leads to small changes in the dihedral angles of the hydantoin fragment (Table 1).

Table 1. Calculated geometry parameters of the ligand (L) and its complexes $(\mathbf{1 , 2})$ (atom numbering in Figures 2-4)

\begin{tabular}{llll}
\hline Parameters & $\begin{array}{l}\text { Ligand } \\
(\mathbf{L})\end{array}$ & cis-[Pt(L) $\left.{ }_{2} \mathrm{Cl}_{2}\right](\mathbf{1})$ & cis-[Pd(L) $\left.{ }_{2} \mathrm{Cl}_{2}\right](\mathbf{2})$ \\
\hline$\mu(\mathrm{D})$ & 3.40 & 13.69 & 13.62 \\
\hline Bond lengths $\left(\AA^{\circ}\right)$ & & & \\
\hline M-Cl17 & - & 2.40 & 2.37 \\
M-Cl18 & - & 2.40 & 2.37 \\
M-N14 & - & 2,10 & 2.13 \\
M-N14' & - & 2.10 & 2.13 \\
N3-N14 & 1.39 & 1.43 & 1.42 \\
N3'-N14' & - & 1.43 & 1.42 \\
\hline Angles $\left.{ }^{\circ}\right)$ & & & 105.7 \\
\hline N1 -C2-N3 & 104.7 & 105.6 & 101.1 \\
N1-C5-C4 & 101.2 & 101.1 & 106.4 \\
N3-C4-C5 & 106.7 & 106.4 & 105.7 \\
N1'-C2'-N3' & - & 105.6 & 101.1 \\
N1'-C5'-C4' & - & 101.1 & 106.4 \\
N3'-C4'-C5' & - & 106.4 & 119.0 \\
N3-N14-M & - & 118.5 & 119.0 \\
N3'-N14'-M & - & 118.5 & 84.2 \\
N14-M-C117 & - & 84.2 & 84.3 \\
N14'-M-C118 & - & 84.2 & 94.9 \\
N14-M-N14' & - & 94.9 & 96.4 \\
C117-M-C118 & - & 96.6 & \\
\hline
\end{tabular}




\section{Table 1 (continued)}

\begin{tabular}{llll}
\hline Dihedral angles $\left(^{\circ}\right)$ & & & \\
\hline C2-N3-C4- C5 & -0.3 & -1.9 & -1.92 \\
C2-N1-C5- C6 & 117.1 & 117.9 & 117.9 \\
N1 -C2-N3-C4 & -2.0 & 0.2 & 0.2 \\
N1-C5-C4- N3 & 2.3 & 2.6 & 2.6 \\
N3-C4-C5-C13 & 123.4 & 123.6 & 123.7 \\
N3-N14-M-C117 & - & 99.2 & 98.5 \\
N3-N14-M-Cl18 & - & 99.2 & 98.6 \\
C2-N3-N14-M & - & 52.2 & 51.3 \\
C4-N3-N14-M & - & -121.7 & -123.9 \\
C2'-N3'-N14'-M & - & 53.2 & 51.2 \\
C4'-N3'-N14'-M & - & -121.7 & -123.9 \\
\hline \hline
\end{tabular}

$\mathrm{M}=\mathrm{Pt}$ or $\mathrm{Pd}$

Table 2. The geometrical parameters of hydrogen bonds in cis- $\left[\mathrm{Pt}(\mathrm{L})_{2} \mathrm{Cl}_{2}\right]$ and cis- $\left[\mathrm{Pd}(\mathrm{L})_{2} \mathrm{Cl}_{2}\right]$ complexes calculated at B3LYP/LANL2DZ level

\begin{tabular}{|c|c|c|c|c|}
\hline \multirow{2}{*}{$\begin{array}{l}\text { Contact } \\
\text { D-H...A }\end{array}$} & \multicolumn{3}{|c|}{ Distance $(\AA)$} & \multirow{2}{*}{$\begin{array}{l}\text { Angle }\left(^{\circ}\right) \\
\text { D-H-A }\end{array}$} \\
\hline & $\mathrm{D}-\mathrm{H}$ & H...A & D...A & \\
\hline \multicolumn{5}{|l|}{$c i s-\left[\mathrm{Pt}(\mathrm{L})_{2} \mathrm{Cl}_{2}\right]$} \\
\hline N14-H...O15' & 1.04 & 1.75 & 2.73 & 155.2 \\
\hline N14'-H...O15 & 1.04 & 1.75 & 2.73 & 155.2 \\
\hline \multicolumn{5}{|l|}{ cis- $\left[\mathrm{Pd}(\mathrm{L})_{2} \mathrm{Cl}_{2}\right]$} \\
\hline N14-H...O15' & 1.03 & 1.77 & 2.74 & 154.7 \\
\hline N14'-H...O15 & 1.03 & 1.77 & 2.74 & 154.7 \\
\hline
\end{tabular}

On the basis of the results from the physicochemical investigation and quantum chemical calculations, the following most probable molecular structure of the $\mathrm{Pt}(\mathrm{II})$ (1) and $\mathrm{Pd}(\mathrm{II})$ (2) complexes could be proposed (see Figure 4). 


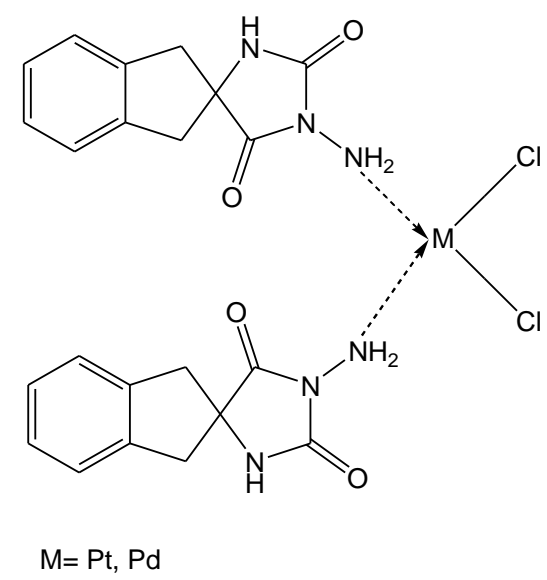

Figure 4. Chemical structure of the complexes (1) and (2).

We evaluated the cytotoxic effects of the ligand $(\mathbf{L})$ and newly synthesized metal complexes $(\mathbf{1 , 2})$ versus the reference antineoplastic agent cisplatin, on K-562 and HL-60 human tumor cell lines, using the standard MTT-dye reduction assay for cell viability. The $\mathrm{IC}_{50}$ values of the synthesized compounds and of the reference drug cisplatin were summarized in Table 3.

Table 3. Cytotoxicity of the ligand $(\mathbf{L})$ and its metal complexes $(\mathbf{1 , 2})$ in comparison to cisplatin

\begin{tabular}{ccc}
\hline \hline \multirow{2}{*}{ Compound } & \multicolumn{2}{c}{$\begin{array}{c}\mathrm{IC}_{50} \text { values }(\mu \mathrm{M}) \\
\text { Cell line }\end{array}$} \\
\hline $\mathbf{L}$ & $\mathrm{K}-562^{\mathrm{a}}$ & $\mathrm{HL}-60^{\mathrm{b}}$ \\
\cline { 2 - 3 } $\mathbf{1}$ & $>200$ & $>200$ \\
$\mathbf{2}$ & $>200$ & 165.2 \\
Cisplatin & $>200$ & $>200$ \\
\hline \hline
\end{tabular}

${ }^{\mathrm{a}} \mathrm{K}-562$ (Chronic myeloid leukemia); ${ }^{\mathrm{b}} \mathrm{HL}-60$ (acute myeloid leukemia)

The results showed that ligand $(\mathbf{L})$ and complexes $(\mathbf{1 , 2})$ have concentration-dependent antiproliferative activity in vitro on the studied cell lines. Pt(II) complex (1) has better cytotoxic activity on HL-60 human tumor cell line, than Pd(II) complex and ligand (L). The Pd(II) complex was less active than the $\mathrm{Pt}(\mathrm{II})$ complex on both cell lines.

\section{Conclusions}

The ligand 1-amino-1,3-dihydrospiro[imidazoline-4,2-indene]-2,5-dione was used to synthesize two new Pt(II) and Pd(II) complexes. The obtained compounds were characterized by elemental analysis, IR, ${ }^{1} \mathrm{H}$ and ${ }^{13} \mathrm{C}$ NMR spectra. DFT investigation of the complexes showed that a cisstructure is preferred. The structures of the complexes are stabilized by formation of internal 
hydrogen bonds and exhibit square planar coordination. In the metal complexes (1,2) the coordination of the ligand to the metal ion is realized through the nitrogen atom of the $\mathrm{NH}_{2}$ group. The complexes were studied for antitumor activity in vitro on K-562 and HL-60 human tumor cell lines. The tested compounds exerted concentration-dependent cytotoxic effects against the tumor cell lines used. The Pt(II) complex (1) showed higher cytotoxic activity on HL-60 cell line than the corresponding palladium complex (2) but both metal complexes have lower activity than the reference drug cisplatin.

\section{Experimental Section}

General. Indene was purchased from Aldrich. Potassium tetrachloroplatinate(II) was purchased from Merck, Germany and potassium tetrachloropalladate(II) from Heraeus GmbH. Elemental analysis was carried out on a "EuroEA 3000 - Single", EuroVectorSpA. The IR spectra were recorded on Thermo Scientific Nicolet iS10 spectrophotometer in the range of $4000-400 \mathrm{~cm}^{-1}$ as an Attenuated Total Reflection Fourier Transform Infrared Spectroscopy (ATR-FTIR). Intensities of reported IR bands are defined as br = broad, $\mathrm{s}=$ strong, $\mathrm{m}=$ medium, and $\mathrm{w}=$ weak. The ${ }^{1} \mathrm{H}$ and ${ }^{13} \mathrm{C}$ NMR spectra were registered on Bruker DRX 250 (250 MHz) and Bruker WM 500 (500 $\mathrm{MHz}$ ) spectrometers in DMSO- $d_{6}$. The mas spectrum of the ligand was recorded on LC-MS (Thermo Scientific q Exactive Plus - Dionex 3000RSLC). Corrected melting points were determined, using a Buchi 535 apparatus.

1-Amino-1,3-dihydrospiro[imidazoline-4,2-indene]-2,5-dione $\quad$ (L). 2-Indanone and 2indanespiro-5'-hydantoin were synthesized from indene according to given procedures. ${ }^{22,23}$ To 2indanespiro-5'-hydantoin $(2.02 \mathrm{~g}, 10 \mathrm{mmol})$ was added hydrazine hydrate $(98 \%, 10 \mathrm{~mL}){ }^{24} \mathrm{The}$ mixture was heated at reflux for $3 \mathrm{~h}$. The final solution was added to cold water $(20 \mathrm{~mL})$ and the resulting precipitate was filtered off and recrystallized from $50 \% \mathrm{EtOH}$, giving white crystals (see Scheme 1). Yield: 1.23 g (57\%), m.p. 206-207 ${ }^{\circ} \mathrm{C} ; \mathrm{M}^{+}=217$. IR(ATR): 3328 br, 3260 br, 3183 m, 3114 m, 1782 s, 1709 s, 1608 s. ${ }^{1} \mathrm{H}-\mathrm{NMR}$ (500 MHz, DMSO-d6, $\delta$, ppm): 8.59 (s, 1H, NH-1); 7.21-7.19 (m, H-Ar); 4.74 (s, 2H, NH$), 3.33\left(\mathrm{~d}, 2 \mathrm{H}, \mathrm{CH}_{2}-\mathrm{A}, J 17 \mathrm{~Hz}\right.$ ); 3.03 (d, 2H, $\mathrm{CH}_{2}-\mathrm{B}, J 17$ $\mathrm{Hz}) .{ }^{13} \mathrm{C}-\mathrm{NMR}\left(125 \mathrm{MHz}, \mathrm{DMSO}-d_{6}, \delta, \mathrm{ppm}\right): 175.9\left(\mathrm{C}=\mathrm{O}-4^{\prime}\right) ; 156.7\left(\mathrm{C}=\mathrm{O}-2^{\prime}\right) ; 140.5,127.9$, 125.2 (C-Ar); 66.0 (C-5'); $44.5\left(\mathrm{CH}_{2}\right)$.

cis-Bis(1-amino-1,3-dihydrospiro[imidazoline-4,2-indene]-2,5-dione)-dichlorido

platinum(II) - cis-[PtL $\mathbf{C l}_{2}$ ] (complex 1). A solution of $\mathbf{L}(0.109 \mathrm{~g}, 0.48 \mathrm{mmol})$ in aq EtOH was added dropwise to an aq solution of $\mathrm{K}_{2}\left[\mathrm{PtCl}_{4}\right](0.100 \mathrm{~g}, 0.24 \mathrm{mmol})$ with constant stirring. The homogenous solution obtained was stirred for 9-10 h at rt. Subsequently, the reaction mixture was concentrated and cooled to $4{ }^{\circ} \mathrm{C}$. The yellow precipitate obtained was filtered off, washed several times with $\mathrm{Et}_{2} \mathrm{O}$ and dried in a vacuum desiccator. The product was recrystallized from EtOH. The substance is soluble in DMSO and slightly soluble in water. Yield: $0.069 \mathrm{~g} \mathrm{(41 \% ),} \mathrm{m.p.} \mathrm{263-264}$ ${ }^{\circ} \mathrm{C}$ (dec.). IR(ATR): 3367 br, 3259 br, 3185 br, 3147 m, 1771 m, 1722 m, 1575 w. ${ }^{1} \mathrm{H}-\mathrm{NMR}$ (250 
MHz, DMSO- $\left.d_{6}, \delta, \mathrm{ppm}\right): 8.58$ (s, $\left.1 \mathrm{H}, \mathrm{NH}-1\right) ; 7.25-7.16$ (m, CH-Ar); 7.19 (s, 2H, NH ); 3.37 (d, $\left.2 \mathrm{H}, J 16.8 \mathrm{~Hz}, \mathrm{CH}_{2}-\mathrm{A}\right) ; 3.00$ (d, $\left.2 \mathrm{H}, J 16.8 \mathrm{~Hz}, \mathrm{CH}_{2}-\mathrm{B}\right) .{ }^{13} \mathrm{C}-\mathrm{NMR}\left(62.5 \mathrm{MHz}, \mathrm{DMSO}-d_{6}, \delta, \mathrm{ppm}\right)$ : $176.5\left(\mathrm{C}=\mathrm{O}-4^{\prime}\right) ; 157.4\left(\mathrm{C}=\mathrm{O}-2^{\prime}\right) ; 141.2$, 128,8, $125.9(\mathrm{C}-\mathrm{Ar}) ; 66.8\left(\mathrm{C}-5{ }^{\prime}\right) ; 45.2\left(\mathrm{CH}_{2}\right)$. Anal. calcd. for $\mathrm{PtC}_{22} \mathrm{H}_{22} \mathrm{~N}_{6} \mathrm{O}_{4} \mathrm{Cl}_{2}(\%)$ : C, 37.72; H, 3.17; N, 12.00. Found (\%): C, 37.49; H, 3.75; N, 12.44 .

cis-Bis(1-amino-1,3-dihydrospiro[imidazoline-4,2-indene]-2,5-dione)-dichlorido palladium(II) - cis-[PdL $\left.\mathbf{C l}_{2}\right]$ (complex 2). Solutions of $\mathrm{K}_{2}\left[\mathrm{PdCl}_{4}\right]$ and of 1-amino-1,3dihydrospiro[imidazoline-4,2-indene]-2,5-dione were prepared. The solution of $\mathbf{L}(0.139 \mathrm{~g}, 0.61$ $\mathrm{mmol})$ in aq EtOH was added dropwise to an aq solution of $\mathrm{K}_{2}\left[\mathrm{PdCl}_{4}\right](0.100 \mathrm{~g}, 0.30 \mathrm{mmol})$ with constant stirring. The homogenous solution was stirred for a further $6 \mathrm{~h}$. The light-yellow product obtained was filtered off, washed several times with water and dried in a vacuum desiccator. The substance is soluble in DMSO and poorly soluble in water. The product was recrystallized from EtOH. Yield: 0.078 g (42\%), m.p. 281-282 ${ }^{\circ} \mathrm{C}$ (dec.). IR(ATR): 3387 br, 3260 br, 3194 br, 3149 m, 1770 m, 1715 m, 1575 w. ${ }^{1} \mathrm{H}-\mathrm{NMR}$ (250 MHz, DMSO-d6, $\delta$, ppm): 8,59 (s, 1H, NH-1); 7.257.16 (m, CH-Ar); 7.20 (s, 2H, NH ); 3.37 (d, 2H, J $16.8 \mathrm{~Hz}, \mathrm{CH}_{2}-\mathrm{A}$ ); 3.00 (d, 2H, J $16.8 \mathrm{~Hz}$, $\left.\mathrm{CH}_{2}-\mathrm{B}\right) .{ }^{13} \mathrm{C}-\mathrm{NMR}\left(62.5 \mathrm{MHz}, \mathrm{DMSO}-d_{6}, \delta, \mathrm{ppm}\right): 174.4\left(\mathrm{C}=\mathrm{O}-4^{\prime}\right) ; 157.4\left(\mathrm{C}=\mathrm{O}-2^{\prime}\right) ; 141.1$, 128.6, 125.9 (C-Ar); $66.8\left(\mathrm{C}^{-5}\right)$; $45.2\left(\mathrm{CH}_{2}\right)$. Anal. calcd. for $\mathrm{PdC}_{22} \mathrm{H}_{22} \mathrm{~N}_{6} \mathrm{O}_{4} \mathrm{Cl}_{2}(\%)$ : C, 43.19; $\mathrm{H}$, $3.62 ; \mathrm{N}, 13.74$. Found (\%): C, 43.34; H, 3.39; N, 13.87.

Computational Details. The molecular structures and vibrational spectra of the ligand $(\mathbf{L})$ and its complexes $(\mathbf{1 , 2})$ were studied by computational methods. All theoretical calculations were performed using the Gaussian 03 package of programs. ${ }^{25}$ Optimization of the structures of the ligand and its complexes was carried out by hybrid DFT calculations, employing the B3LYP (Becke's three-parameter non-local exchange) ${ }^{26,27}$ correlation functional and $6-311++\mathrm{G}^{* *}$ basis set for all non-metal atoms and LANL2DZ basis set for the metal center.

Pharmacology. The cell lines used for the experiments were: (i) K-562 (Chronic myeloid leukemia, derived from a 53-year-old woman with chronic myeloid leukemia, (CML) in blast crisis in 1970); (ii) HL-60 (acute myeloid leukemia, established from the peripheral blood of a patient with acute promyelocyte leukemia). The cell lines were obtained from DSMZ German Collection of Microorganisms and Cell Cultures and were well validated in our laboratory as a proper test system for metal complexes. Their DSMZ catalogue numbers are as follows: K-562 (ACC 10) and HL-60 (ACC 3).

Cytotoxicity of the compounds was assessed using the MTT [3-(4,5-dimethylthiazol-2-yl)-2,5diphenyltetrazolium bromide] dye reduction assay as described by Mossman $^{28}$ with some modifications. ${ }^{29}$ Exponentially growing cells were seeded in 96 -well microplates $(100 \mu \mathrm{L} /$ well at a density of $3.5 \times 10^{5}$ cells $/ \mathrm{mL}$ for the adherent and $1 \times 10^{5}$ cells $/ \mathrm{mL}$ for the suspension cell lines) and allowed to grow for $24 \mathrm{~h}$ prior the exposure to the studied compounds. Stock solutions of the organic compound (L) and its platinum and palladium complexes $(\mathbf{1 , 2})$ were freshly dissolved in DMSO and then promptly diluted in RMPI-1640 growth medium, immediately before treatment 
of the cells. Our preceding experience with water-insoluble metal complexes, including cisplatin has indicated that the dose-response curves following dissolution in water or stock solution in DMSO (which is then promptly diluted in aqueous phase) overlap and there is no significant modulation of the individual cell lines chemosensitivity. At the final dilutions the solvent concentration never exceeded $0.5 \%$. Cells were exposed to the tested agents for $72 \mathrm{~h}$, whereby for each concentration a set of 8 separate wells was used. Every test was run in triplicate, i.e. in three separate microplates. After incubation with the tested compounds MTT solution $(10 \mathrm{mg} / \mathrm{mL}$ in PBS) aliquots were added to each well. The plates were further incubated for $4 \mathrm{~h}$ at $37{ }^{\circ} \mathrm{C}$ and the formazan crystals formed were dissolved by adding $110 \mu \mathrm{L}$ of $5 \% \mathrm{HCOOH}$ in 2-propanol. Absorption of the samples was measured by an ELISA reader (UniscanTitertec) at $580 \mathrm{~nm}$. Survival fraction was calculated as percentage of the untreated control. The experimental data were processed using GraphPad Prizm software and were fitted to sigmoidal concentration/response.

\section{References}

1. Reedijk, J. Curr. Opin. Chem. Biol. 1999, 3, 236-240. https://doi.org/10.1016/S1367-5931(99)80037-4

2. Forastiere, A.; Koch W.; Trotti, A.; Sidranski, D. N. Engl. J. Med. 2001, 345, 1890-1900. https://doi.org/10.1056/NEJMra001375

3. Latorre, A.; De Lena, M.; Catino, A.; Crucitta, E.; Sambiasi, D.; Guida, M.; Misino, A.; Lorusso, V. Int. J. Oncology 2002, 21, 179-186. https://doi.org/10.3892/ijo.21.1.179

4. Markman, M. Expert Opin. Drug Saf. 2003, 2, 597-607. https://doi.org/10.1517/14740338.2.6.597

5. Hartmann, I.; Lipp, H. Expert Opin. Pharmacother. 2003, 4, 889-901. https://doi.org/10.1517/14656566.4.6.889

6. Kosmider, B.; Wyszynska, K.; Janik-Spiechowicz, E.; Osiecka, R.; Zyner, E.; Ochocki, J.; Ciesielska, E.; Wasowicz, W. Mutat. Res./Gen. Toxic. Environment. Mutag. 2004, 558, 93110. https://doi.org/10.1016/j.mrgentox.2003.11.006

7. Giraldi, S.; Sava, G.; Bertoli, G.; Mestroni, G.; Zassinovich, G. Cancer Res. 1977, 37, $2662-$ 2666. PubMed 872094.

8. Graham, R.; Williams, D. J. Inorg. Nucl. Chem. 1979, 41, 124. https://doi.org/10.1016/0022-1902(79)80496-0

9. Sava, G.; Alessio, E.; Bergamo, A.; Mestroni, G. In Metallopharmaceuticals, Clarke, M., Sadler, P. Eds., Springer: Berlin, 1999; pp143-169. https://doi.org/10.1007/978-3-662-03815-4_6

10. Rosenberg, B.; Van Camp, L.; Trosko, J.; Mansour, V. Nature 1969, 222, 385-386. https://doi.org/10.1038/222385a0 
11. Divsalar, A.; Saboury, A.; Mansouri-Torshizi, H.; Hemmatnejad, B. Bull. Korean Chem. Soc. 2006, 27, 1801-1808. https://doi.org/10.5012/bkcs.2006.27.11.1801

12. Mansouri-Torshizi, H., Moghaddam, M.I.; Divsalar, A.; Saboury, A. Bioorg. Med. Chem. 2008, 16, 9616-9625.

https://doi.org/10.1016/j.bmc.2008.08.021

13. Saeidfar, M.; Masouri-Torshizi, H.; Behbehani, G.; Divsalar, A.; Saboury, A. Bull. Korean Chem. Soc. 2009, 30, 1951-1955. https://doi.org/10.5012/bkcs.2009.30.9.1951

14. Butour, S.; Wimmer, F.; Wimmer, S.; Castan, P. Chem. Biol. Inter. 1997, 104, 165-178. https://doi.org/10.1016/S0009-2797(97)00022-7

15. Jakupec, M.; Galanski, M.; Keppler, B. Rev. Physiol. Biochem. Pharmacol. 2003, 146, 1-54. https://doi.org/10.1007/s10254-002-0001-X

16. Kalinowska-Lis, U.; Ochocki, J.; Matlawska-Wasowska, K. Coord. Chem. Rev. 2008, 252, 1328.

https://doi.org/10.1016/j.ccr.2007.07.015

17. Quiroga, A.; Navarro-Ranninger, C. Coord. Chem. Rev. 2004, 248, 119-133.

https://doi.org/10.1016/j.cct.2003.11.004

18. Puszyńska-Tuszkanow, M.; Daszkiewicz, M.; Maciejewska, G.; Adach, A.; Cieślak-

Golonka, M. Struct. Chem. 2010, 21, 315-321.

https://doi.org/10.1007/s11224-009-9533-x

19. Beard, R. L.; Vuligonda, V.; Vu, T.; Donello, J. E.; Viswanath, V.; Garst, M. E. PCT Int. Appl. 2013, WO 2013071203 A1.

20. Nakanishi, K., Infrared Absorption Spectroscopy, Holden-Day: San Francisco and Nankodo Company Limited, Tokyo, 1964.

21. Kushev, D.; Enchev,V.; Naydenova, E.; Detcheva, R.; Spassovska, N.; Grancharov, K., Croat. Chem. Acta 2009, 82, 607-612.

22. Horan, J. E.; Schiessler, R. W. Org. Synth. 1961, 41, 53-55.

https://doi.org/10.15227/orgsyn.041.0053

23. Davidson, J. S. J. Chem. Soc. 1964, 4646. https://doi.org/10.1039/jr9640004633

24. Pesquet, A.; Daich, A.; Luc Van Hijfte J. Org. Chem. 2006, 71, 5303-5311. https://doi.org/10.1021/jo060616s

25. Gaussian 03, Revision C.02, Frisch, M. J.; Trucks, G. W.; Schlegel, H. B.; Scuseria, G. E.; Robb, M. A.; Cheeseman, J. R.; Montgomery, Jr., J. A.; Vreven, T.; Kudin, K. N.; Burant, J. C.; Millam, J. M.; Iyengar, S. S.; Tomasi, J.; Barone, V.; Mennucci, B.; Cossi, M.; Scalmani, G.; Rega, N.; Petersson, G. A.; Nakatsuji, H.; Hada, M.; Ehara, M.; Toyota, K.; Fukuda, R.; Hasegawa, J.; Ishida, M.; Nakajima, T.; Honda, Y.; Kitao, O.; Nakai, H.; Klene, M.; Li, X.; Knox, J. E.; Hratchian, H. P.; Cross, J. B.; Bakken, V.; Adamo, C.; Jaramillo, J.; Gomperts, R.; Stratmann, R. E.; Yazyev, O.; Austin, A. J.; Cammi, R.; Pomelli, C.; Ochterski, J. W.; Ayala, 
P. Y.; Morokuma, K.; Voth, G. A.; Salvador, P.; Dannenberg, J. J.; Zakrzewski, V. G.; Dapprich, S.; Daniels, A. D.; Strain, M. C.; Farkas, O.; Malick, D. K.; Rabuck, A. D.; Raghavachari, K.; Foresman, J. B.; Ortiz, J. V.; Cui, Q.; Baboul, A. G.; Clifford, S.; Cioslowski, J.; Stefanov, B. B.; Liu, G.; Liashenko, A.; Piskorz, P.; Komaromi, I.; Martin, R. L.; Fox, D. J.; Keith, T.; Al-Laham, M. A.; Peng, C. Y.; Nanayakkara, A.; Challacombe, M.; Gill, P. M. W.; Johnson, B.; Chen, W.; Wong, M. W.; Gonzalez, C.; and Pople, J. A.; Gaussian, Inc., Wallingford CT, 2004.

26. Stephens, P. J.; Devlin, F. J.; Chabalowski, C. F.; Frisch, M. J. J. Phys. Chem. 1994, 98, 1162311627. https://doi.org/10.1021/j100096a001

27. Lee, C. T.; Yang, W. T.; Parr, R. G. Phys. Rev. B 1988, 37, 785-789. https://doi.org/10.1103/PhysRevB.37.785

28. Mosmann, T. J. Immunol. Methods 1983, 65, 55-63. https://doi.org/10.1016/0022-1759(83)90303-4

29. Konstantinov, S.; Eibl, H.; Berger, M. Br. J. Haematol. 1999, 107, 365-374. https://doi.org/10.1046/j.1365-2141.1999.01700.x 